\title{
Examining the Role of Motivation and Competence on Employee Performance with Discipline as Moderating Variable
}

\author{
Dwi Widiastuti*, Wiyarni Wiyarni, Eko Sudjawoto \\ Post Graduate STIE Malangkucecwara Malang
}

\author{
*Corresponding Author: Dwi Widiastuti, Post Graduate STIE Malangkucecwara Malang
}

\begin{abstract}
In the era, where technology and civilization are advanced, the human resources who have high competence, enthusiasm, and discipline in carrying their jobs are very important. This study aims to investigate the role of motivation, competence, and discipline on employee performance. There are two research questions that have to be answered in this study. They are: how motivation and competence affected employee performance; and how discipline moderated the motivation and competence on employee performance. This study conducted in civil service and education training district regencies in Pasuruan, East Java, Indonesia. The sampling technique used in this study is the saturated sample method, which is the number of samples equal to the population that was 40 employees. Using multiple regression analysis, this study found that motivation and competency simultaneously have a significant effect on the performance. If the employee can join unite physiological needs, a sense of security, social, appreciation and selfactualization as an indicator of motivation with motives, traits, self-concept, knowledge and skills as indicators of competence, it will have a positive and significant effect on improving performance. This study also found that work discipline variable can strengthen the relationship of motivation and competence on employee performance.
\end{abstract}

Keywords: Motivation, Competence, Discipline, Employee Performance

\section{BACKGROUND}

In the globalization era, where everything changes rapidly, an organization or institution is required to make adjustments in all aspects in the organization. Human resources is part of a progress in science, development, and technology. Therefore, in this era where technology and civilization are very advanced, the competent human resources who have high enthusiasm and discipline in carrying out their roles and functions both for individual and organizational goalsare much needed. Škrinjarić and Polona (2020) state that mismatches in competences and motivation and organization are negatively associated with firm performance, with motivation and organization having the most significant effect. Whereas Pawirosumarto, Purwanto and Muzaffar (2017) found that motivation and discipline have positive and significant effect on employee performance.

According to Dessler (2003), employee performance is a work performance, which is a comparison between work results that are seen clearly with work standards set by the organization. Then Robbins (2003) defines performance is a result achieved by employees in their work according to certain criteria that apply to a job.Besides good performance, to ensure the achievement of alignment of goals, the leadership of an organization can pay attention by providing motivation. According to Hasibuan (2010) motivation is providing the driving force that creates the excitement of one's work so that they are willing to work together, work effectively, and be integrated with all their efforts to achieve satisfaction. Motivationis very important for employees because it makes someone work well so they can achieve an optimal result and support the achievement of company goals.

In achieving good performance for the company, discipline is needed to support the smooth running of all organizational activities so that organizational goals can be achieved optimally. According to Hasibuan (2010), discipline is one's awareness and willingness to obey all company regulations and social norms. Disciplineis a tool used by managers to communicate with their employees. This communication can make they arewilling to change behavior as well as effort to raise awareness and willingness tocomply with all rules and norms (Rivai and Sagala, 2009).Discipline can create a pleasant work atmosphere and employee motivation will also increase. This makes employees able to 
carry out their work with full awareness.Based on the background description above and see the importance of motivation, competence and work discipline in determining employee performance, this study wants to examine the role of motivation and competence on performance with work discipline as a moderating variable in civil service and education training district regencies in Pasuruan, East Java, Indonesia.

\section{LiteratURE REVIEW}

\subsection{Employee Performance}

Each employee is required to make a positive contribution through good performance, considering the performance of the organization depends on the performance of its employees.Performance is a real behavior that is displayed by everyone as a work performance produced by employees in accordance with their role in the company (Rivai, 2010). Mangkuprawiraand Hubeis (2007) states that employee performance is the result of certain work processes that are planned at the time and place of the employee and the organization concerned. Whereas according to Dessler (2003), employee performance is a work performance, which is a comparison between work results that are seen clearly with work standards set by the organization.

The employee performance needs to assess in order to give the right feedback to behavioral changetoward increased productivity and expected performance. Employee performance assessment can be invarious forms such as key performance indicators or key performance index that is basically anobjective and systematic process to collect, analyze and use the employee performance information to determine theefficiency and effectiveness of employees' duties and achievement. Employee performanceassessment is based on understanding of knowledge, skill, expertise and behavior necessaryto do a good job.Another definition of performance is a systematic process that strives to improve organizationalperformance by focusing on its employees' performance (Armstrong, 2010). Moreover, Armstrong (2010) states that performance is also a comprehensive termthat encompasses setting objectives, laying down goals, turning over responsibilities,evaluating and enlightening performance, training and rising employees, rewarding andstimulating talent. Bernardin and Russel (2010: 156) suggest that a person's performance can be measured based on 5 criteria generated from the work concerned, namely: quality, quantity, timelines, effectiveness, and interpersonal impact.

\subsection{Motivation}

Motivation is the driving force in someone to behave and work with enthusiasm and good in accordance with the duties and obligations that have been given to him. Motivation teaches how to encourage the morale of subordinates so that they want to work hard by using all their abilities and skills to be able to advance and achieve company goals. According to Robbins (2003), motivation is a desire to do something by high level effort to achieve theorganization's goals. Moreover, Robbins (2003) state that motivation is as a process that explains the intensity, way, and persistence of an individual to achieve his goals. Mangkunegara (2005: 61) states that motivation is formed from the attitudes of employees in dealing with work situations in the company (situation). Motivation is a condition or energy that moves employees who are directed to achieve the goals of the organization. The mental attitude of employees who are positively towards the work situation to achieve maximum performance.The indicators of motivation for this research is adopted from Maslow theory. The hierarchy of needs theory from Abraham Maslow (1954) consists of:Physiological Needs, Security Needs, Social Needs, Esteem Needs, and Self-actualizing Needs.

According to Hasibuan (2010), the purpose of providing motivation for an employee isto provide benefits to the employee. Besides, givingmotivation to employees can also provide benefits to company organizations such as: can increase employee productivity; can encourage employee morale and passion for work; can maintain employee stability; can improve employee morale job satisfaction; can create an atmosphere and employee work relationships; can increase employee creativity and participation; can improve employee welfare; can increase discipline and reduce absenteeism; and can heighten employees' sense of responsibility towards their duties.

\subsection{Competence}

Competence as a basic characteristic of a person that allows them to excel superior performance in their work. Competence is also a part of a deep personality and is inherent in someone with predictable behavior in various circumstances and work assignments. By evaluating one's 
competency, we will be able to predict the person's performance. Employees who are placed in certain assignments that have been assessed will know what competencies are needed, and what methods must be taken to achieve promotion to the next level of position.McClelland (1973) defines competence as a basic characteristic of personnel which is a determining factor in the success or failure of a person in doing a job or in certain situations. Hutapea and Nuriana (2008) also explained that competency is a picture of what a person must know or do in order to carry out his work well. According to Mohklas (2015), competence is an ability to carry out a job or task based on skills and knowledge and is supported by the work attitude required by the job. Therefore, competence shows the skills or knowledge that are characterized by professionalism in a particular field as something that is most important and also as a superior of that field.

According to Spencer and Spencer (1993), there are five types of indicators in measuring competence. Those indicators are motives, traits, self-concept, knowledge, and skills. Motive is something that is consistently thought or desired by people who cause action.Motives encourage, direct, and choose behavior towards certain actions or goals. Traits are physical characteristics and consistent responses to situations or information.Self-concept is the attitude, values, or self-image of a person. Confidence is the belief that people can be effective in almost every situation is part of people's selfconcept.Knowledge is information that is owned by people in a specific field. Knowledge is a complex competency. Finally, skills are the ability to do certain physical or mental tasks. Mental competence or cognitive skills including analytical and conceptual thinking.

\subsection{Discipline}

According to Simamora (2004) discipline is a procedure that corrects or punishes subordinates for violating rules or procedures. Work discipline is a tool used by managers to communicate with employees so that they are willing to change a behavior and as an effort to increase one's awareness and willingness to obey all company regulations and applicable social norms (Rivai, 2010).Discipline is an attitude and behavior that intends to obey all organizational regulations based on self-awareness to adjust to organizational regulations. Therefore, it can be concluded that work discipline is a real practice of the employees of the regulations contained in an organization. In this case discipline is not only in the form of obedience but also the responsibility given by the organization, based on that it is expected that the effectiveness of employees will increase and behave as well as behave in discipline.

Indicators of work discipline used in this study are adopted from Hasibuan (2010). Those indicators are attitudes, norms, and responsibilities. Attitudeis mental and employee behavior that comes from the awareness or willingness of himself in carrying out the duties and regulations of the company. Normsare rules about what can and should not be done by employees during in the company and as a reference in attitude. While responsibility is the ability to carry out tasks and regulations within the company. Completing work at a specified time, employees must be responsible for the work by completing work on time determined by the company.

\section{RESEARCH FRAMEWORK}

Research framework of this study can be shown in figure 1 below:

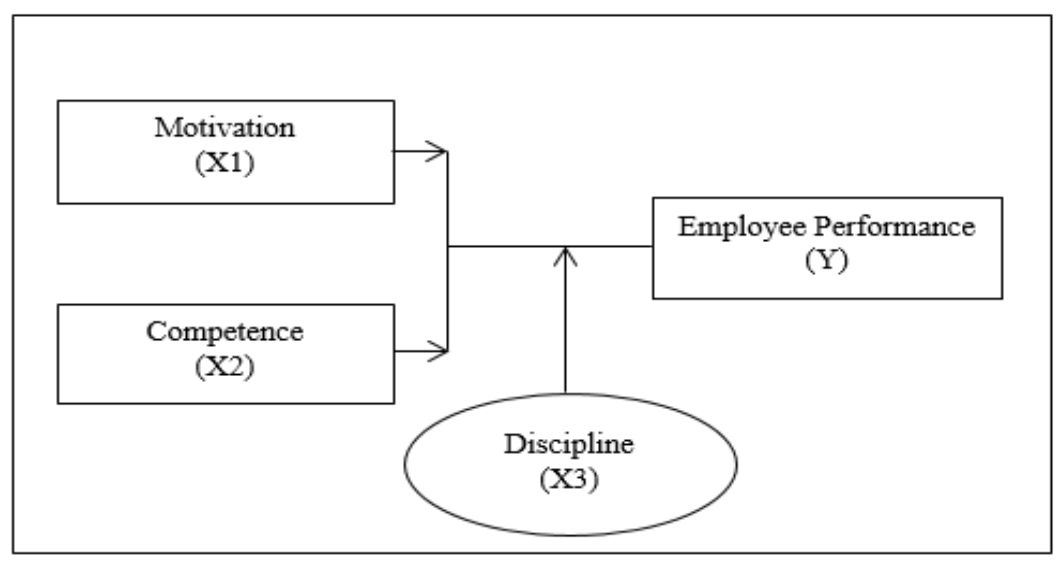

Figure1 
Examining the Role of Motivation and Competence on Employee Performance with Discipline as Moderating Variable

\subsection{Research Hypothesis}

Based on the research framework above, the hypothesis of this study are:

H1: There are a significant and positive effect of motivation and competence on employee performance

$\mathrm{H} 2$ : There are a significant and positive effect of motivation and competence on employee performance with discipline as moderating variable.

\subsection{Research Method}

\subsubsection{Research Design}

This study is based on a survey employing questionnaire on respondents' perceptions.The questionnaire is designed by using Likert Scale. The Likert Scale is used to measureattitudes, opinions and perceptions of a person on a social phenomenon.In this study, social phenomenon raised is at Civil Service and Education Training District Regencies in Pasuruan, East Java, Indonesia.

\subsubsection{Variables And Indicators}

Variables and indicators of this study can be seen in the table 1 below:

Table1. Variables, Definition, Indicators

\begin{tabular}{|c|c|c|}
\hline Variables & Definitions & Indicators \\
\hline $\begin{array}{l}\text { Motivation } \\
\text { (X1) }\end{array}$ & $\begin{array}{l}\text { A process that explains the intensity, } \\
\text { direction, and perseverance of an individual to } \\
\text { achieve his goals }\end{array}$ & $\begin{array}{l}\text { 1. Physiological Needs } \\
\text { 2. The need for security } \\
\text { 3. Social needs } \\
\text { 4. The need for appreciation } \\
\text { 5. The need for self-actualization }\end{array}$ \\
\hline $\begin{array}{l}\text { Competence } \\
\text { (X2) }\end{array}$ & $\begin{array}{l}\text { The ability to do a job / task based on skills } \\
\text { and knowledge and is supported by the work } \\
\text { attitude required by the job }\end{array}$ & $\begin{array}{ll}\text { 1. } & \text { Motive } \\
\text { 2. } & \text { Traits } \\
\text { 3. } & \text { Self-Concept } \\
\text { 4. } & \text { Knowledge } \\
\text { 5. } & \text { 5. Skills } \\
\end{array}$ \\
\hline $\begin{array}{l}\text { Discipline } \\
\text { (X3) }\end{array}$ & $\begin{array}{l}\text { An attitude and behavior that intends to obey } \\
\text { all organizational rules based on self- } \\
\text { awareness to adjust to organizational } \\
\text { regulations }\end{array}$ & $\begin{array}{ll}\text { 1. } & \text { Presence } \\
\text { 2. Compliance with work regulations } \\
\text { 3. Compliance with work standards } \\
\text { 4. High level of vigilance } \\
\text { 5. Work ethically }\end{array}$ \\
\hline $\begin{array}{l}\text { Employee } \\
\text { Performance } \\
\text { (Y) }\end{array}$ & $\begin{array}{l}\text { A work that has been achieved by an } \\
\text { employee in carrying out a job to achieve the } \\
\text { goals of the organization }\end{array}$ & $\begin{array}{ll}\text { 1. } & \text { Quality } \\
\text { 2. } & \text { Quantity } \\
\text { 3. } & \text { Timeliness } \\
\text { 4. } & \text { Effectiveness } \\
\text { 5. } & \text { Relationships between individuals }\end{array}$ \\
\hline
\end{tabular}

\subsection{Population and Sample}

The population in this study is employees at Civil Service and Education Training District Regencies in Pasuruan, East Java, Indonesia. Total population is 40 employees. The sampling technique in this study is the saturated sample method, which is the number of samples equal to the population. Therefore, the sample in this study was 40 employees.

\subsection{Data Analysis Method}

There are five-steps to analyze the data in this research, namely, descriptive statistics,validity and reliability testing, classic assumption test, data analysis (multipleregression analysis, F-test, t-test, R2 test) and the correlation between dimensions. Dataprocessing and analysis is conducted with the help of SPSS (Statistical Product for Service Solution) version 22.0.

\subsection{Results and Discussion}

\subsubsection{Validity And Reliability}

Validity test is used to determine the feasibility of the items in a list of questions in defining variables. A question can be said to be valid if the value of $r$-count which is the value of the corrected item is 
Examining the Role of Motivation and Competence on Employee Performance with Discipline as Moderating Variable

greater than r-table. The total correlation of r-tables (at the 5\% significance level) obtained through DF (Degree of Freedom) (Bhuono 2005).The result of validity test can be seen in the following table:

1. Motivation

Table2. Validity Test of Motivation

\begin{tabular}{|l|l|l|l|l|}
\hline No. & Item & r-count & r-table & Results \\
\hline 1. & X1.1 & .821 & .2404 & Valid \\
\hline 2. & X1.2 & .859 & .2404 & Valid \\
\hline 3. & X1.3 & .768 & .2404 & Valid \\
\hline 4. & X1.4 & .800 & .2404 & Valid \\
\hline 5. & X1.5 & .772 & .2404 & Valid \\
\hline
\end{tabular}

Source: data from statistical proses

2. Competence

Table3. Validity Test of Competence

\begin{tabular}{|l|l|l|l|l|}
\hline No. & Items & r-count & r-table & Results \\
\hline 1. & X2.1 & .702 & .2404 & Valid \\
\hline 2. & $\mathrm{X} 2.2$ & .756 & .2404 & Valid \\
\hline 3. & $\mathrm{X} 2.3$ & .756 & .2404 & Valid \\
\hline 4. & $\mathrm{X} 2.4$ & .836 & .2404 & Valid \\
\hline 5. & $\mathrm{X} 2.5$ & .847 & .2404 & Valid \\
\hline
\end{tabular}

Source: data from statistical proses

3. Discipline

Table4. Validity Test of Discipline

\begin{tabular}{|l|l|l|l|l|}
\hline No. & Items & r-count & r-table & Results \\
\hline 1. & X3.1 & .811 & .2404 & Valid \\
\hline 2. & X3.2 & .898 & .2404 & Valid \\
\hline 3. & X3.3 & .845 & .2404 & Valid \\
\hline 4. & X3.4 & .874 & .2404 & Valid \\
\hline 5. & X3.5 & .740 & .2404 & Valid \\
\hline
\end{tabular}

Source: data from statistical proses

4. Employee Performance

Table5. Validity Test of Employee Performance

\begin{tabular}{|l|l|l|l|l|}
\hline No. & Items & r-count & r-table & Results \\
\hline 1. & Y1 & .705 & .2404 & Valid \\
\hline 2. & Y2 & .703 & .2404 & Valid \\
\hline 3. & Y3 & .810 & .2404 & Valid \\
\hline 4. & Y4 & .797 & .2404 & Valid \\
\hline 5. & Y5 & .721 & .2404 & Valid \\
\hline
\end{tabular}

Source: data from statistical proses

Based on the tables above, it is known that the calculated $r$ value is greater than $r$-table so that it can be said that the whole question is valid. That is, each questionnaire instrument used is precisely a measure of motivation, competence, work discipline and performance.

Reliability test is a measure of the stability and consistency of respondents in answering questions that are dimensions of a variable and arranged in a questionnaire form. The measuring instrument that will be used is Cronbach's alpha through the Excel Statistic Analysis \& SPSS computer program. Reliability of a variable is said to be good if it has a Cronbach's alpha value of 0.60 (Bhuono, 2005: 72). The reliability test results for each variable are summarized in the following table:

Table6. Result of Reliability Test

\begin{tabular}{|l|l|l|l|}
\hline Variabel & Cronbach's Alpha & Minimal Value & Results \\
\hline X1.1 & .939 & .60 & Reliabel \\
\hline X1.2 & .939 & .60 & Reliabel \\
\hline X1.3 & .939 & .60 & Reliabel \\
\hline X1.4 & .944 & .60 & Reliabel \\
\hline
\end{tabular}


Examining the Role of Motivation and Competence on Employee Performance with Discipline as Moderating Variable

\begin{tabular}{|l|l|l|l|}
\hline X1.5 & .943 & .60 & Reliabel \\
\hline $\mathrm{X} 2.1$ & .941 & .60 & Reliabel \\
\hline $\mathrm{X} 2.2$ & .938 & .60 & Reliabel \\
\hline $\mathrm{X} 2.3$ & .940 & .60 & Reliabel \\
\hline $\mathrm{X} 2.4$ & .938 & .60 & Reliabel \\
\hline $\mathrm{X} 2.5$ & .937 & .60 & Reliabel \\
\hline $\mathrm{X} 3.1$ & .940 & .60 & Reliabel \\
\hline $\mathrm{X} 3.2$ & .939 & .60 & Reliabel \\
\hline $\mathrm{X} 3.3$ & .938 & .60 & Reliabel \\
\hline $\mathrm{X} 3.4$ & .938 & .60 & Reliabel \\
\hline $\mathrm{X} 3.5$ & .939 & .60 & Reliabel \\
\hline Y1 & .940 & .60 & Reliabel \\
\hline Y2 & .937 & .60 & Reliabel \\
\hline Y3 & .939 & .60 & Reliabel \\
\hline Y4 & .942 & .60 & Reliabel \\
\hline Y5 & .943 & .60 & Reliabel \\
\hline
\end{tabular}

Source: data from statistical proses

Based on the table above, it can be seen that the reliability test results of the entire questionnaire itemsis above 0.6 or is included in the reliable criteria.

\subsection{Classical Assumptions}

This study used several classical assumptions. They are multicollinearity test, heterocedastisity, autocorrelation, and normality test. Multicollinearity test is a test to see whether there is a high correlation between independent variables in a multiple linear regression model by looking at the Collinearity Statistics Column whose tolerance value must be greater than 0.1.From the statistic's output, all variables have a value of more than 0.1 (motivation has value 0.702 , competence has value 0.484 , and discipline has value 0.577 ) so that it can be concluded that the regression model does not occur / is free from multicollinearity or in other words the model can be used.

Heterokedastisitas test is a test to see whether there is a variance in the residual variance of one observation to another by looking at the plot graph between the predicted values of the dependent variable (ZPRED) with the residual SRESID. From the statistic's output, heteroscedasticity does not occur because there is no clear pattern and the points spread above and below the number 0 on the $\mathrm{Y}$ axis. Therefore, it can be said heteroscedasticity test is fulfilled. The autocorrelation test is a test to predict whether or not the equation is worth using the Durbin Watson value.From the statistic's output, $\mathrm{n}=40$ and the number of independent variables $=3$, the values of $\mathrm{dl}$ and du are 1,338 and 1,659 , so that it can be du $<\mathrm{DW}<4$-du that is $1,659<1,918<2,341$ so that it can be concluded that autorkorrelation symptoms do not occur. The last classical assumption used in this study is normality test. Normality Test is a test to see whether the residual value is normally distributed or not by looking at the results of the histogram and normal probability plots.From the statistic's output, the curved lines form like mountains and look perfect with symmetrical legs, so it can be concluded that the data in the study are normally distributed.

\subsection{Hypothesis Test}

The influence of motivation, competence and work discipline on performance in the Civil Service and Education Training District Regencies in Pasuruan, East Java, Indonesia was analyzed using multiple regression equations. If the significance value $<0.05$, then there is a significant effect or if t table $>$ from $\mathrm{t}$ arithmetic then $\mathrm{H} 0$ is accepted (no effect), but if $\mathrm{t}$ table $<\mathrm{t}$ arithmetic $\mathrm{H} 0$ is rejected (there is influence).

Table7. Output ANOVA a

\begin{tabular}{|l|l|l|l|l|l|l|}
\hline Model & Sum of Squares & df & Mean Square & F & Sig. \\
\hline \multirow{5}{*}{1} & Regression & 4.917 & 2 & 2.458 & 17.248 & $.000^{\mathrm{b}}$ \\
\cline { 2 - 7 } & Residual & 5.274 & 37 & .143 & & \\
\cline { 2 - 6 } & Total & 10.191 & 39 & & & \\
\hline
\end{tabular}


From the results of the SPSS output in the table above shows the p-value $0,000<0.005$, the meaning is significant, while the F count is 17,248> from the F table 2.71 (df1 = 4-1 = 3 and df $2=40-4=36$ ). Therefore, the competency and motivation variables jointly affect employee performance, it can be concluded that $\mathrm{H} 1$ is accepted.

The second hypothesis is the influence of motivation and competence on employee performance with work discipline as a moderating variable. According to Ghozali (2011), interaction test or also called Moderated Regression Analysis (MRA) is a linear multiple regression application in which the regression contains interaction elements (multiplication of two or more independent variables). From the SPSS program, the results in the following table are obtained:

Table8. Coefficients ${ }^{a}$

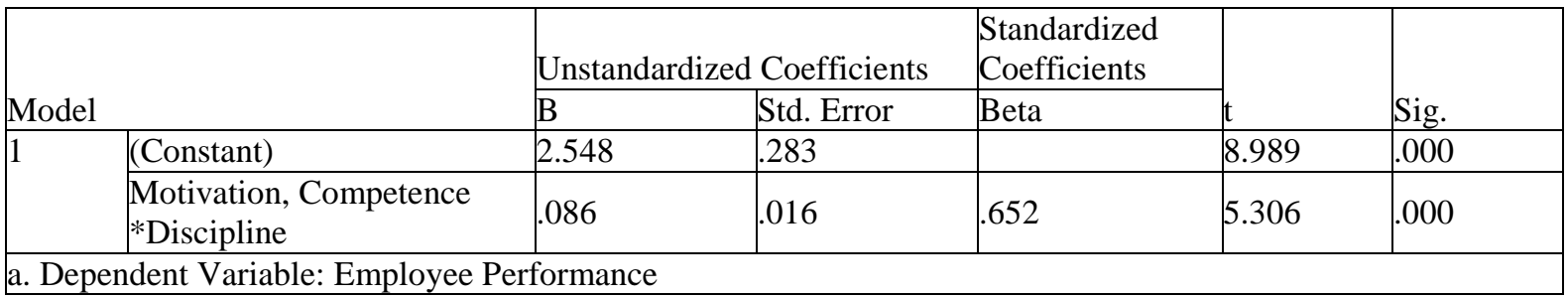

Based on the output of the SPSS program in the table above, it can be explained as follows:

1. A value of 2,548 is the result of a constant, meaning that without any influence from the three independent variables and other factors, the employee performance variable has a value of that constant that is equal to 2,548 .

2. The regression coefficient of 0.086 states that each increase in the competency and motivation variables that is interacted with the work discipline variable given to employees by one score will increase employee performance by 0.086 without being influenced by other factors. Motivation and competencies will be further enhanced if strengthened by work discipline in its effect on performance, with a significance level of $0,000<0.05$, while t-test 5.306 $>$ t-table 2.009 , then it is stated that, work discipline variables can function as moderating variables, with thus $\mathrm{H} 2$ is received.

Table9. Model Summary

\begin{tabular}{|l|l|l|l|l|}
\hline Model & $\mathrm{R}$ & $\mathrm{R}$ Square & Adjusted R Square & Std. Error of the Estimate \\
\hline 1 & $.652^{\mathrm{a}}$ & .426 & .410 & .39250 \\
\hline \multicolumn{2}{|l|}{ a. Predictors: (Constant), MOTIVATION COMPETENCE * DISCIPLINE } \\
\hline
\end{tabular}

Based on the table above, Adjusted R Square has a value of 0.426 or $42.6 \%$. This shows that $42.6 \%$ of the dependent variable (employee performance) is explained by the independent variable (motivation and competence), while the remaining $57.4 \%$ is explained by other variables not included in this study.

\section{DISCUSSION}

With the proven significant influence of motivation and competence on employee performance, the Head of Civil Service and Education Training District Regencies in Pasuruan, East Java, Indonesia can make encouraging efforts by providing motivation in the form of rewards for achievement, can be in the form of promotion or in the form of certain incentives that are appropriate with statutory provisions.

In addition to improving employee competence, education and training can continue to be carried out in accordance with the development of information technology, because what is still an obstacle so far, one of which is the ability of employees to use information technology is still weak.The strict and uncompromising application of enforcing rules is powerful enough to provide the ability of discipline to personnel in carrying out daily tasks.

Motivation that has been formed and maintained will provide encouragement for employees of the Civil Service and Education Training District Regencies in Pasuruan, East Java, Indonesia to improve their performance, then competence influences work motivation. With intellectual competency, emotional competence and social competence will provide encouragement to employees of the Civil 
Service and Education Training District Regencies in Pasuruan, East Java, Indonesia for achievement, affiliation and form the power to improve their performance.

Moderated by work discipline, the results of this study prove a significant effect on performance. Work discipline variables can strengthen the relationship of motivation and competence on performance. The synergy of motivation and competence will provide optimal performance results for employees of theCivil Service and Education Training District Regencies in Pasuruan, East Java, Indonesia.

With the proven influence of motivation and competence on performance by moderating employee work discipline, the Head of the Civil Service and Education Training District Regencies in Pasuruan, East Java, Indonesia can make efforts to encourage work discipline as already done, such as the absence of finger / faceprint and followed by morning ceremony so if the employee arrives late then the employee will feel reluctant.The strict and uncompromising application of enforcing rules is powerful enough to provide employees with the ability to discipline in carrying out daily tasks.

\section{CONCLUSION}

Based on the results of the statistical analysis, it has been tested simultaneously that motivation and competence have a significant effect on the performance of the staff of the Civil Service and Education Training District Regencies in Pasuruan, East Java, Indonesia with a calculated F value of 17,248 and a $F$ value of table 2.71 or a calculated $F$ value greater than the value of the $F$ table. The statistic test obtained a significant value of $0.000<0.05$, this states that the competency and motivation together has a positive and significant effect on performance. Ifthe staff of the Civil Service and Education Training District Regencies in Pasuruan, East Java, Indonesia can jointly unite physiological needs, a sense of security, social, appreciation and self-actualization as an indicator of motivation with motives, traits, self-concept, knowledge and skills as indicators of competence, it will have a positive and significant effect on improving performance.

The results of this research simultaneously prove a significant influence on performance. With high motivation and supported by good competence will be able to provide performance to employees which will ultimately create optimal effectiveness among all employees.In this study it was found that the influence of these two factors amounted to $54.6 \%$ while the rest were influenced by other factors such as work environment, psychological factors, organizational culture and others.

\section{REFERENCES}

[1] Amstrong, Michael. 2010. Armstrong's handbook of Human Resorce Management Practice. $11^{\text {th }}$ edition. United Kingdom: Kogan Page Limited.

[2] Bernardin, H.John\&Russel. 2010. Human Resource Management. New York: McGraw-Hill.

[3] Bhuono, Agung Nugroho, 2005. Strategijitumemilihmetodestatistik Penelitiandengan SPSS. Penerbit Abdi, Yogyakarta.

[4] Dessler, G. 2003. Human Resources Management, International Edition. New Jersey, Prentice Hall.

[5] Hasibuan, Malayu. S.P., 2010. Manajemen Sumber Daya Manusia. Jakarta: BumiAksara.

[6] Hutapea, Parulina\&Nuriana, Thoha. 2008. Kompetensi plus: teori, desain, kasusdanpenerapanuntuk HR danorganisasi yang dinamis. Jakarta: GramediaPustakaUtama.

[7] Mangkunegara, Anwar Prabu, 2005. Manajemen Sumber Daya Manusia Perusahaan, Penerbit: PT Remaja Rosda Karya, Bandung.

[8] Mangkuprawira, S., \&Hubeis A. V. 2007.ManajemenMutuSumberDayaManusia. Penerbit Ghalia Indonesia, Bogor

[9] Maslow, A. H. 1954. Motivation and personality. Harpers.

[10] Mohklas. 2015. Pengaruh Kompetensi Dan Motivasi Terhadap Kinerja Pegawai Dengan Komunikasi SebagaiVariabel Moderating (StudiPada Kecamatan Gayamsari Kota Semarang. Fokus Ekonomi, 10 (2).

[11] Pawirosumarto, Suharno,Purwanto, K. S., \&Muzaffar M. 2017. Factors affecting employee performance of PT.Kiyokuni Indonesia. International Journal of Law and Management. 59 (4), 602-614.

[12] Rivai, Veithzal\&Sagala, Ella Jauvani. 2009. Manajemen Sumber Daya Manusiauntuk Perusahaan dari Teorike Praktik. Jakarta: PT RajaGrafindo

[13] Rivai, Veithzal. 2010. Manajemen Sumber Daya Manusiauntuk Perusahaan. Jakarta: PT Raja Grafindo Persada. 
Examining the Role of Motivation and Competence on Employee Performance with Discipline as Moderating Variable

[14] Robbins, S.P. 2003. Organizational Behavior, $6^{\text {th }}$ Edition. New Jersey, Prentice Hall.

[15] Simamora, Henry. 2004. Manajemen Sumber Daya Manusia CetakanKe 1.Bandung: CV. PustakaSetia.

[16] Škrinjarić, Bruno\&Polona, Domadenik. 2020. Examining the role of keycompetences in firm performance. International Journal of Manpower, 41 (4), 391-416.

[17] Spencer, Lyle M \& Signe M. Spencer. 1993. Competence at Work Models for Superior Performance. New York: John Wiley \& Sons Inc.

\section{AUTHORS' BIOGRAPHIES}

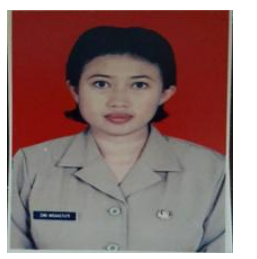

Dwi Widiastuti, is a student of Post Graduate STIE Malangkucecwara Malang, East Java, Indonesia.

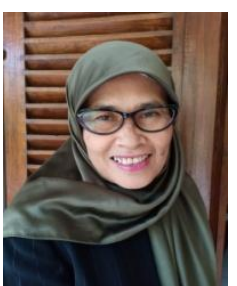

Wiyarni Wiyarni, is a lecturer in Post Graduate STIE Malangkucecwara Malang, East Java, Indonesia

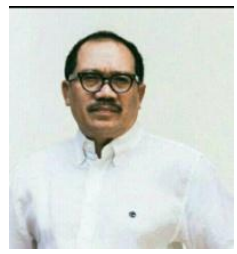

Eko Sudjawoto, is a lecturer in Post Graduate STIE Malangkucecwara Malang, East Java, Indonesia

Citation: Dwi Widiastuti, Wiyarni Wiyarni, Eko Sudjawoto. "Examining the Role of Motivation and Competence on Employee Performance with Discipline as Moderating Variable" International Journal of Managerial Studies and Research (IJMSR), vol 8, no .8, 2020, pp. 1-9. doi: https://doi.org/10.20431/23490349.0808001.

Copyright: (C) 2020 Authors. This is an open-access article distributed under the terms of the Creative Commons Attribution License, which permits unrestricted use, distribution, and reproduction in any medium, provided the original author and source are credited. 